\title{
Ecological Relevance of Hemolymph Total Protein Concentration in Seven Unrelated Crustacean Species from Different Habitats Measured Predictively by a Density-Salinity Refractometer
}

\author{
Simonetta Lorenzon, ${ }^{1}$ Marzia Martinis, ${ }^{2}$ and Enrico A. Ferrero ${ }^{2}$ \\ ${ }^{1}$ Dipartimento di Oceanografia Biologica, Istituto Nazionale di Oceanografia e di Geofisica Sperimentale, Via A. Piccard 54, \\ S. Croce, 34010 Trieste, Italy \\ ${ }^{2}$ Department of Life Sciences, University of Trieste, Via Giorgieri 7, 34127 Trieste, Italy
}

Correspondence should be addressed to Simonetta Lorenzon, slorenzon@ogs.trieste.it

Received 29 March 2011; Revised 6 June 2011; Accepted 9 September 2011

Academic Editor: Garth L. Fletcher

Copyright (C) 2011 Simonetta Lorenzon et al. This is an open access article distributed under the Creative Commons Attribution License, which permits unrestricted use, distribution, and reproduction in any medium, provided the original work is properly cited.

\begin{abstract}
In recent years, blood metabolites have been investigated as a tool for monitoring physiological condition in wild or cultured crustaceans exposed to different environmental conditions. Blood protein levels fluctuate with changes in environmental and physiological conditions and play fundamental roles in the physiology of crustaceans from $\mathrm{O}_{2}$ transport to reproduction up to stress responses. Proteins are major contributors to hemolymph density, and the present study correlates the easy and low cost measure of hemolymph density by a density-salinity refractometer with the total protein concentration, measured with a colorimetric method. Moreover, the study evaluates the accuracy of the relationship and provides a conversion factor from hemolymph density to protein in seven species of crustaceans, representative of taxa far apart in the phylogenetic tree and characterized by different life habits. Measuring serum-protein concentration by using a refractometer can provide a nondestructive field method to assess crustacean populations/species protein-related modifications of physiological state without need of costly laboratory facilities and procedures.
\end{abstract}

\section{Introduction}

In recent years blood metabolites have been investigated as a tool for monitoring physiological condition in wild or cultured crustaceans exposed to different environmental conditions [1-3]. Hemocyanin is the major hemolymph constituent $(>60 \%)$; the remaining proteins (in order of concentration) include coagulogen, apohemocyanin, hormones, and lipoproteins.

Blood protein levels fluctuate with changes in environmental and physiological conditions and play fundamental roles in the physiology of crustaceans from $\mathrm{O}_{2}$ transport to reproduction up to stress responses [4-9]. In fact, moulting, reproduction, nutritional state, infection, hypoxia, and salinity variations are the major factors affecting the relative proportions and total quantities of the hemolymph proteins [10-12].

The shrimp immune system response is largely based on proteins. These are involved for example in recognizing foreign particles [13] and in trapping foreign invading organisms and prevent blood loss upon wounding $[14,15]$.

Recently, Rosas et al. [2] showed that shrimp, are well adapted to use protein as a source of energy and molecules. Blood protein concentration has been found since long to be related to nutritional condition in a number of crustaceans $[16,17]$. The concentration of protein in the blood is a possible index of nutritional condition, which decreases in starved prawns and lobsters $[1,18,19]$. The moult cycle imposes constraints on protein levels, blood-proteins typically drop just before moulting as water is taken up and protein is used 
to synthesize the new exoskeleton [20]. Protein levels then gradually build up again after ecdysis as water is replaced by tissue $[17,21,22]$. Consequently, measuring the blood protein concentration of a crustacean sample group can provide valuable information to identify its condition [23].

The concentration of protein in the blood is directly proportional to the refractive index of the blood. Measurements of the blood refractive index therefore offer potential as a field method for assessing the nutritional condition of prawns [17].

Colorimetric procedures are generally the preferred choice to measure serum protein concentration; however, they are expensive, time consuming, and not easily performed in the field. Because of ease, rapid mode of operation, and small amount of material required, measuring serum protein concentration using a refractometer provided a nondestructive field method to assess crustacean's physiological state (stress, immunoresponse, nutrition status, molt, etc.) without any need of laboratory facilities; the refractometer is a simple, small portable instrument that can be used in the field or on crustacean farms.

The method is already recommended for grading the condition of live $H$. americanus arriving at factories, allowing industry operators to make decisions about the marketing of individual lobsters based on information from a single drop of blood $[24,25]$. It has also been used for studies of live lobsters, crabs, and penaeid shrimp $[1,17,26]$.

The aim of the present study is (1) to determine in several species of crustaceans, representative of taxa far apart in the phylogenetic tree and characterized by different life habits, their level of total protein concentrations in the hemolymph by colorimetric method, tested under the most varied environmental and physiological conditions; (2) to measure hemolymph density of the same sample by means of a density-salinity refractometer; (3) to relate the two variables by linear regression and to check eventually whether the latter measure can be used as a suitable predictor of the former.

\section{Material and Methods}

2.1. Data Set. The data presented in this work represent a data set collected in our laboratory during the past ten years when carrying out routine measures of hemolymph protein and density on different crustacean species and under several different experimental settings [3, 9]. The data pooled from samples were neither selected or sorted for sex, size, or any reproductive or other physiological state. They represent therefore the amplest variability available as possible in life conditions and adaptations. The data approximate the protein concentration range in living conditions both immediately after fishing, transport, or after acclimatization in the lab.

In particular, data used were collected by measuring hemolymph parameters in the following.

The freshwater crayfish Astacus leptodactylus (Eschscholtz, 1823) (Decapoda, Astacidae) was imported commercially from Turkey into Italy (Olivotto, Udine), and it is an economically important aquacultured species as well as an invasive species in some European countries.

The rock pool shrimp Palaemon elegans (Rathke, 1837) (Decapoda, Caridea), an eurythermal and euryhaline species distributed widely along the coastal areas of Europe, were caught in the Gulf of Trieste (Upper Adriatic Sea) by local fishery.

The crab Carcinus aestuarii (Nardo, 1847) (Decapoda, Brachyura) an eurythermal and euryhaline littoral species was also caught as artisanal fishery by-catch in the Gulf of Trieste.

The subtidal crab Cancer pagurus (Linnaeus, 1758) (Decapoda, Brachyura) is found on bedrock including under boulders, mixed coarse grounds, and offshore in muddy sand. Dwelling on lower shore, shallow sublittoral, and offshore to about $100 \mathrm{~m}$., they were provided by commercial import to Italy (Fiorital srl, Venezia) from Cherbourg (France).

The American lobster Homarus americanus (H. Milne Edwards, 1837) (Decapoda, Nephropidae) may be found from the low tide mark out to depths of approximately $400 \mathrm{~m}$, they were provided by commercial import to Italy (Fiorital srl, Venezia) from USA North-East Coast.

The mud shrimp Upogebia pusilla (Petagna, 1792) (Decapoda, Thalassinidea) lives in burrows in intertidal shallow water, and finally the mantis shrimps Squilla mantis (Stomatopoda, Squillidae), were both caught in the Gulf of Trieste by artisanal fishery. Crabs, lobsters, and, in some regions also, the mantis shrimps are economically very important and after catch they are shipped and stored alive in tank systems at commercial plant until sold. Palaemon elegans and Upogebia pusilla have a local market as living baits.

These species are representative of taxa far apart in the phylogenetic tree (Stomatopoda versus Decapoda) dwelling in different habitats with different ranges of salinity and temperature; for example, $S$. mantis is a benthic stenohaline species adapted to a constant relatively high salinity environment; P. elegans and C. aestuarii are exposed to variable salinity and temperature in the estuarine-marine gradient where $U$. pusilla is fossorial, while A. leptodactylus is a freshwater species.

2.2. Animal Maintenance. But for the animals bled immediately after landing or arrival, the others were acclimatized at the Dep. Biology (presently Dep. Life Sciences) in aquaria of adequate size, less $1 \%$ weight to water volume, surface, and shelters, with closed circuit filtered water, controlled temperature, salinity, illumination, oxygen within the range tested in the experimental conditions. Animal were fed twice a week ad libitum with bits of fish, molluscs, and shrimps but feeding was discontinued $48 \mathrm{~h}$ before experimental bleeding. Only hard shelled animals were used.

2.3. Determination of Hemolymph Parameters. Animals were blotted dry and at least $100 \mu \mathrm{L}$ of hemolymph was withdrawn from the pericardial sinus or from the articular membranes of pereiopods (depending on the species) with a sterile $1 \mathrm{~mL}$ syringe fitted with a $25 \mathrm{G}$ needle. Hemolymph was 
centrifuged for $1 \mathrm{~min}$ at $10,300 \mathrm{~g}$ and $4^{\circ} \mathrm{C}$, and the plasma fraction was quickly frozen at $-20^{\circ} \mathrm{C}$ and stored until required for study.

As a control, the measure of hemolymph density and total protein was performed in 10 samples of hemolymph from $H$. americanus and 10 from S. mantis before and after centrifugation in case hemocytes could affect the reading of density in whole blood. No significant difference $(P>$ 0.05 ) was recorded and the procedure therefore accepted. The immediate density reading after bleeding rules out the requirement of anticoagulant, neither this was required for storing frozen plasma: the occasional clotted hemolymph samples upon thawing $(<2 \%)$ were discarded.

Total plasma protein (TP) concentrations were determined by a modified Biuret test using screen point (Hospitex Diagnostics srl., Florence, Italy) multichannel (420-590 nm) photometric reading system, a clinical chemistry analyser with reagents in prefilled cuvettes (Kit by Hospitex Diagnostics srl., Florence, Italy). Standard solution calibrations were used between samples.

The density of the hemolymph was obtained by the use of a density-salinity refractometer (Scubla s.n.c., Udine, Italy) with automatic temperature compensation. The range of density measured by the refractometer was $1000-1070 \mathrm{~g} \mathrm{~L}^{-1}$ with a precision to the nearest $1 \mathrm{gL}^{-1}$, and a dilution $1: 1$ $\mathrm{v} / \mathrm{v}$ with distilled water was performed when hemolymph value overrode the upper limit. No significant $(P>0.05)$ difference in the level of measured protein was recorded between untreated and calculated from diluted hemolymph (data not shown).

2.4. Statistical Analysis. All statistics were performed by using Statistica 7 (R) for Windows package. Descriptive statistical analysis was used to characterize hemolymph parameters.

Data are given as arithmetic means \pm standard errors. Analysis of variance (ANOVA) was used to test the null hypotheses that means were equal between species for each parameter and then all the data were tested by the Tukey HSD post hoc test. A probability value of less than 0.05 of the statistical tests between the experimental values (mean \pm ES) was considered significant. Normal distribution of the parameter was analyzed using the Shapiro-Wilk test. Pearson's correlation between density of the hemolymph and TP was determined and a linear regression fit tested.

A paired $t$-test was used to evaluate differences between total plasma protein assessed with both the refractometry and the photometric methods. Level of significance accepted $(P<0.05)$.

\section{Results}

Figure 1(a) shows the hemolymph level of total protein (TP) and the density (Figure 1(b)) in the seven species of crustaceans. The minimum level of total protein is revealed in Squilla mantis $(n=191)$ with a mean of $2.84 \pm$ $0.09 \mathrm{~g} \mathrm{dL}^{-1}$ followed by Astacus leptodactylus ( $n=46$; $\left.3.32 \pm 0.25 \mathrm{~g} \mathrm{dL}^{-1}\right)$, Carcinus aestuarii $(n=779 ; 4.01 \pm$ $\left.0.07 \mathrm{~g} \mathrm{dL}^{-1}\right)$, Upogebia pusilla $\left(n=79 ; 4.41 \pm 0.14 \mathrm{~g} \mathrm{dL}^{-1}\right)$, Homarus americanus $\left(n=500 ; 4.45 \pm 0.09 \mathrm{~g} \mathrm{dL}^{-1}\right)$, Cancer pagurus $\left(n=114 ; 5.31 \pm 0.17 \mathrm{~g} \mathrm{dL}^{-1}\right)$, and finally Palaemon elegans with the highest level of protein $(n=164 ; 6.48$ $\left.\pm 0.17 \mathrm{~g} \mathrm{dL}^{-1}\right)$. The TP of each group results significantly different from all the others (ANOVA $F=179.953, P<$ 0.001), exceptions are detailed in Figure 1(a).

Looking at the density of the hemolymph (Figure 1(b)) the lowest level is recorded in A. leptodactylus (1034.8 \pm $\left.2.07 \mathrm{~g} \mathrm{~L}^{-1}\right)$, with $S$. mantis with a density of $1038.9 \pm$ $0.85 \mathrm{~g} \mathrm{~L}^{-1}$, followed by C. aestuarii $\left(1049.78 \pm 0.66 \mathrm{~g} \mathrm{~L}^{-1}\right)$, H. americanus $\left(1052.0 \pm 0.74 \mathrm{~g} \mathrm{~L}^{-1}\right)$, C. pagurus $(1059.2 \pm$ $\left.1.14 \mathrm{~g} \mathrm{~L}^{-1}\right)$, $U$. pusilla $\left(1062.4 \pm 1.56 \mathrm{~g} \mathrm{~L}^{-1}\right)$, and again $P$. elegans show the highest density value of $1087.1 \pm 1.99 \mathrm{~g} \mathrm{~L}^{-1}$. The hemolymph density of each group results significantly different from all the others (ANOVA $F=75.623, P<$ 0.001), exceptions are detailed in Figure 1(b).

Measured density in hemolymph from $H$. americanus samples $(n=10)$ before and after centrifugation showed no significant difference and were, respectively, $1044.7 \pm$ $3.09 \mathrm{~g} \mathrm{~L}^{-1}$ and $1044.2 \pm 3.03 \mathrm{~g} \mathrm{~L}^{-1}(P=0.909)$; $\mathrm{TP}$ was 3.85 $\pm 0.31 \mathrm{~g} \mathrm{dL}^{-1}$ and $3.83 \pm 0.29 \mathrm{~g} \mathrm{dL}^{-1}(P=0.961)$. Similarly in $S$. mantis $(n=10)$ the measure of density was $1038.1 \pm$ $2.50 \mathrm{~g} \mathrm{~L}^{-1}$ and $1039.8 \pm 2.51 \mathrm{~g} \mathrm{~L}^{-1}(P=0.620)$, respectively and protein concentration was $2.64 \pm 0.23 \mathrm{~g} \mathrm{dL}^{-1}$ and $2.62 \pm$ $0.23 \mathrm{~g} \mathrm{dL}^{-1}(P=0.964)$.

The regression lines between hemolymph density and content of TP in the different species are plotted in Figures $2(a)-2(h)$, the statistical data for each species are summarized in Table 1.

The highest correlation is recorded in A. leptodactylus $\left(r^{2}=0.861\right)$ and the lowest in $H$. americanus $\left(r^{2}=\right.$ 0.6103 ). Figure $2(\mathrm{~h})$ shows the relation obtained plotting all the data together and in this case also a high correlation is obtained $\left(r^{2}=0.751\right)$. The data confirm that hemolymph density is a suitable proxy for blood protein. Values of TP obtained with both methods (measured and calculated from hemolymph density) for each species were compared in a two-tailed paired $t$-test and the results are presented in Table 2; a significant correlation is evident in all the species and there are no significant differences in the calculated level of TP versus measured one $(P>0.05)$. Also comparing measured TP with those calculated from the general regression obtained by plotting the data of all species together (Table 2), no significant differences were revealed $(P>0.05)$. The linear regression obtained from measured TP against those calculated from the general regression line is $y=0.7782 x+0.9339 r^{2}=0.7961 P=0.001$.

\section{Discussion}

Moulting, reproduction, nutritional state, infection, stress response, hypoxia, and salinity variations are some of the factors affecting the relative proportions and total quantities of the hemolymph proteins [10-12, 22, 27]. The level of total protein in the hemolymph is also depending on the species, with highest concentrations observed in penaeid and lower ones in freshwater crayfish $[6,7,28,29]$. Moreover 


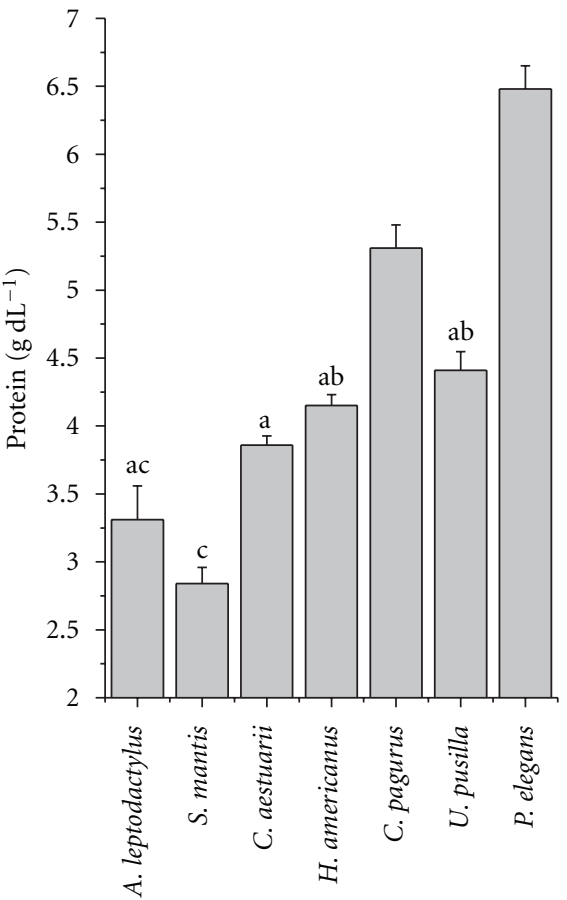

(a)

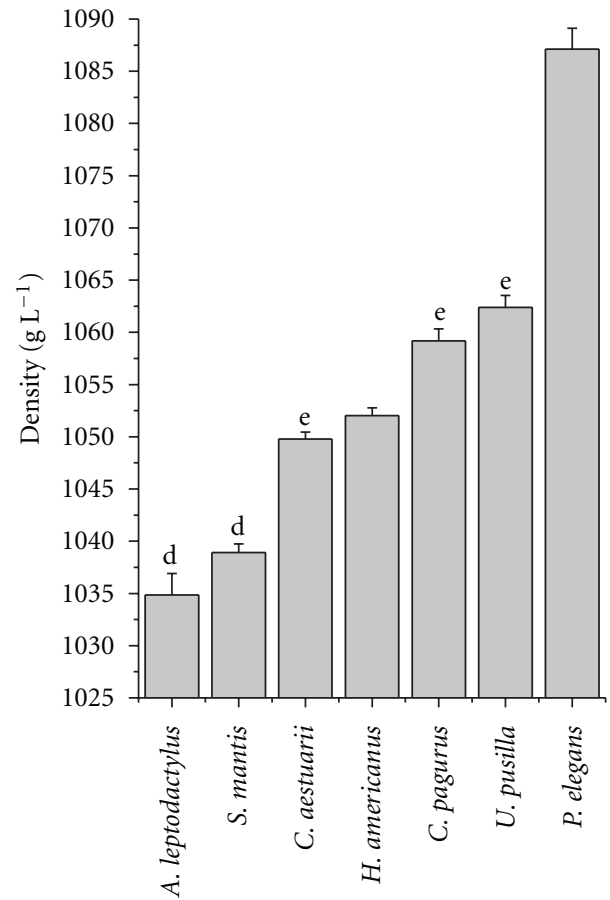

(b)

FIGURE 1: Means and standard error of total protein concentration (a) and hemolymph density (b) in the seven species of crustaceans investigated. Note: same letters denote not significant difference. a: Tuckey HSD $P>0.05$; b: Tuckey HSD $P=0.903$; c: Tuckey HSD $P=0.627$; : Tuckey HSD.

TABLE 1: Statistical data of linear regression.

\begin{tabular}{|c|c|c|c|c|c|c|c|c|c|}
\hline & $n$ & $a$ & Std. Err $a$ & $b$ & Std. Err $b$ & $r^{2}$ & $F$ & $P$ & $\begin{array}{l}\text { Std. Err } \\
\text { Estimate }\end{array}$ \\
\hline P.elegans & 164 & -66.318 & 4.476 & 0.0673 & 0.0041 & 0.6224 & 267.07 & 0.00001 & 1.3376 \\
\hline A. leptodactylus & 46 & -112.243 & 7.011 & 0.112 & 0.0068 & 0.861 & 271.763 & 0.00001 & 0.6380 \\
\hline U. pusilla & 79 & -74.2628 & 5.7762 & 0.074 & 0.00543 & 0.7029 & 185.529 & 0.00001 & 0.6682 \\
\hline S. mantis & 191 & -89.94 & 4.2843 & 0.0893 & 0.00412 & 0.7128 & 469.085 & 0.00001 & 0.6679 \\
\hline C. aestuarii & 656 & -101.76 & 2.453 & 0.101 & 0.00234 & 0.754 & 1853.723 & 0.0001 & 0.936 \\
\hline C. pagurus & 114 & -120.161 & 9.248 & 0.118 & 0.00873 & 0.6390 & 184.05 & 0.00001 & 1.0498 \\
\hline H. americanus & 325 & -86.172 & 4.0164 & 0.0859 & 0.00382 & 0.6103 & 505.843 & 0.00001 & 0.9192 \\
\hline ALL & 1575 & -84.948 & 1.3199 & 0.0846 & 0.00125 & 0.751 & 4565.713 & 0.0001 & 1.009 \\
\hline
\end{tabular}

Note: Std.Err: standard error.

TABLE 2: Two-tailed paired $t$-test between total protein measured and calculated from hemolymph density using the specific (a) or the cumulative regression line (b).

\begin{tabular}{lccccc}
\hline & $n$ & (a) Correlation & $\begin{array}{c}\text { (a) Paired } t \text {-test Sig. } \\
\text { (two tailed) }\end{array}$ & (b) Correlation & $\begin{array}{c}\text { (a) Paired } t \text {-test Sig. } \\
\text { (two tailed) }\end{array}$ \\
\hline P. elegans & 164 & $0.789(P=0.0001)$ & 0.755 & $0.801(P=0.0001)$ & 0.144 \\
A. leptodactylus & 46 & $0.928(P=0.0001)$ & 0.754 & $0.920(P=0.0001)$ & 0.060 \\
U. pusilla & 79 & $0.840(P=0.0001)$ & 0.477 & $0.945(P=0.0001)$ & 0.221 \\
S. mantis & 191 & $0.844(P=0.0001)$ & 0.821 & $0.915(P=0.0001)$ & 0.598 \\
C. aestuarii & 656 & $0.868(P=0.0001)$ & 0.959 & $0.866(P=0.0001)$ & 0.705 \\
C. pagurus & 114 & $0.799(P=0.0001)$ & 0.662 & $0.936(P=0.0001)$ & 0.118 \\
H. americanus & 325 & $0.781(P=0.0001)$ & 0.395 & $0.783(P=0.0001)$ & 0.105 \\
\hline
\end{tabular}




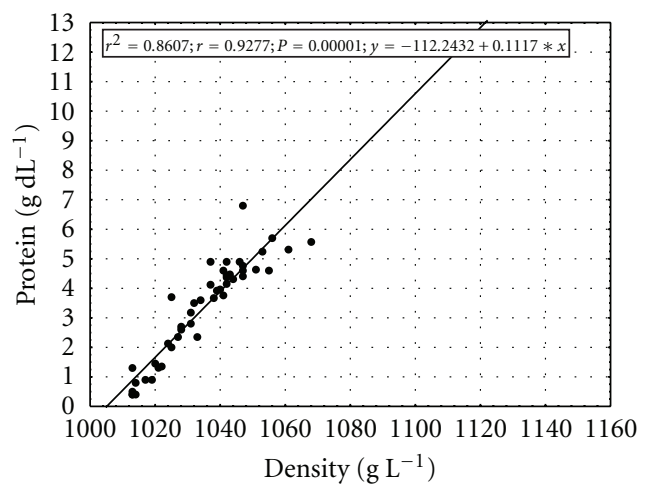

(a)

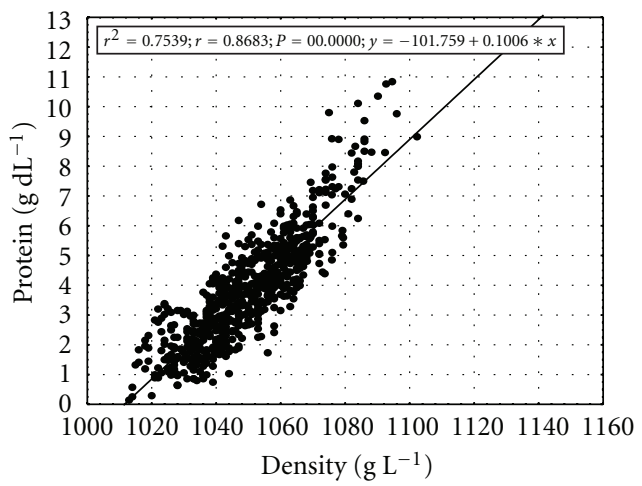

(c)

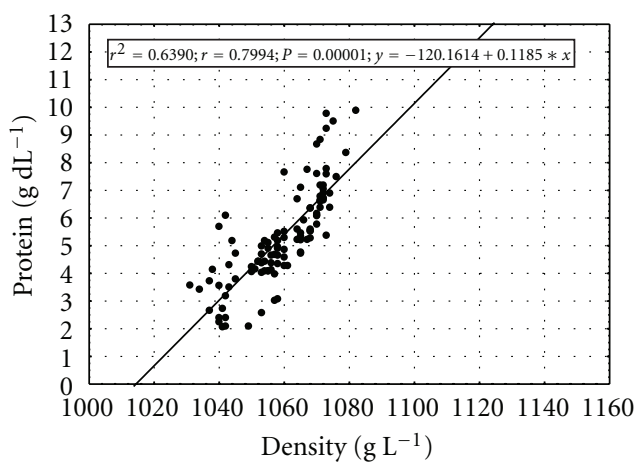

(e)

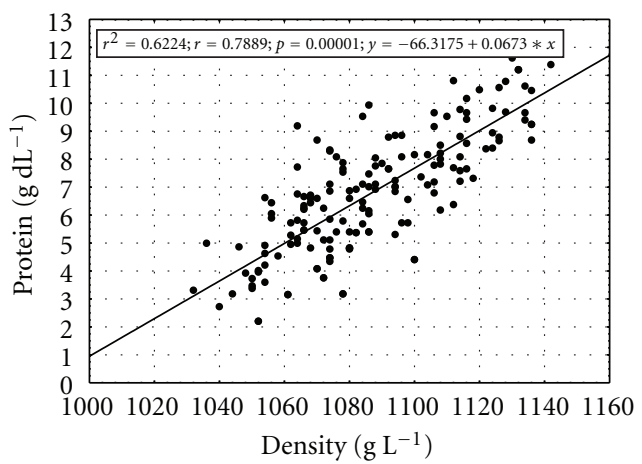

(g)

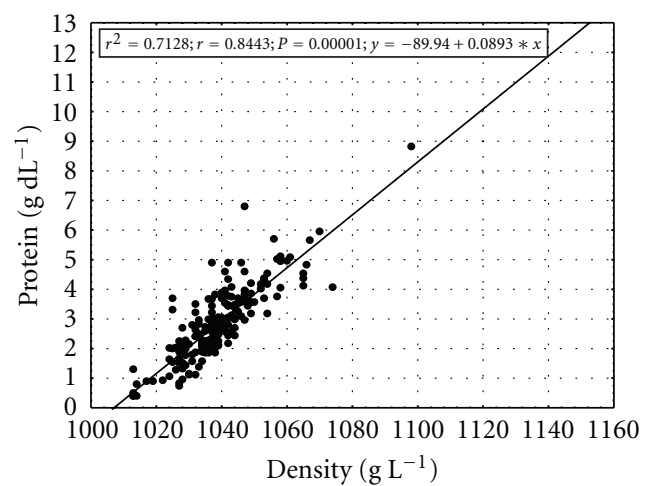

(b)

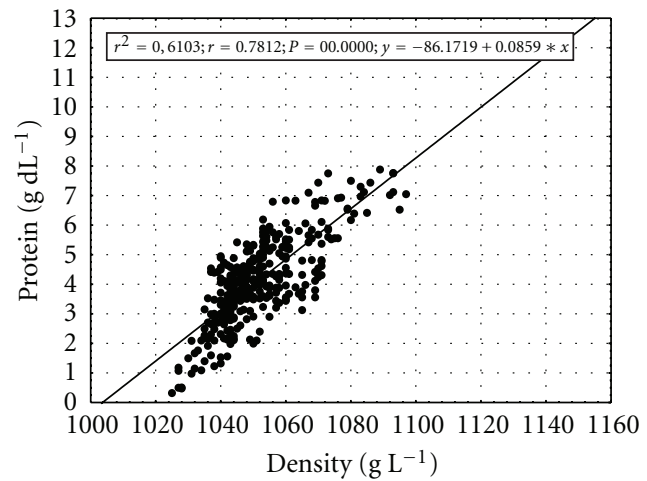

(d)

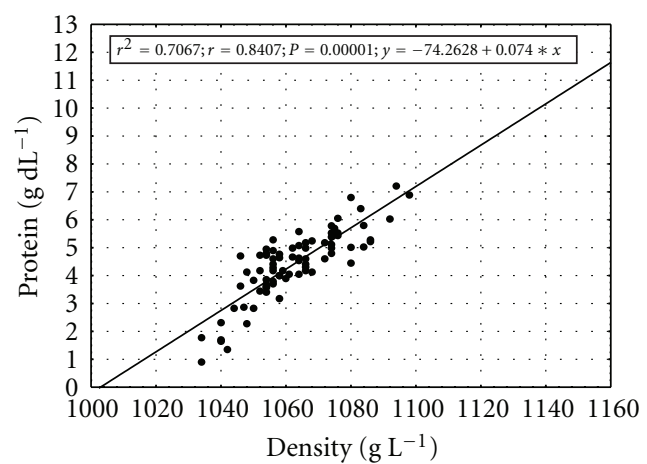

(f)

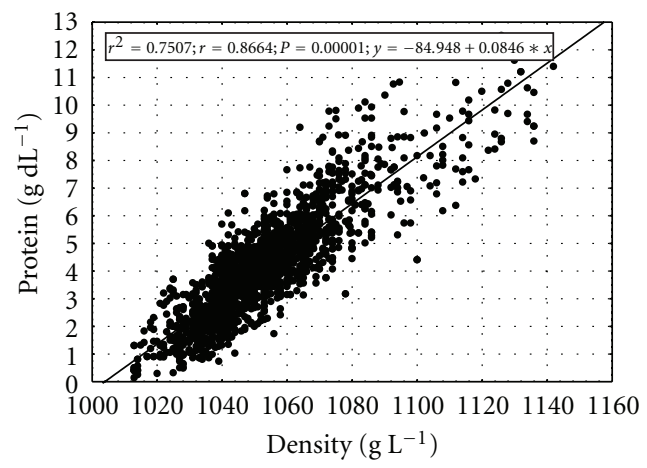

(h)

FIGURE 2: Correlation regression between total protein concentration and density of the hemolymph in: (a) A. leptodactylus $n: 46$; (b) S. mantis n: 191; (c) C. aestuarii $n: 656$; (d) H. americanus $n: 325$; (e) C.pagurus $n: 114$; (f) U. pusilla $n: 79$; (g) P. elegans $n$ : 164; (h) All species plotted together $n: 1575$. 
the level of proteins is the expression of animal's adaptive characteristics and of strategies for acclimatation [29].

Consequently, measuring the protein concentration of a crustacean's blood can provide valuable information to identify its condition [23].

The results presented here confirm the use of hemolymph density measured by refractometry as a suitable proxy for blood protein. Moreover, the efficacy of this use is demonstrated in seven crustacean species representative of taxa even far apart in their phylogenetical relationship (e.g., Stomatopoda versus Decapoda) and characterized by different life habits and habitats with different range of salinity and temperature.

In fact, we studied C. aestuarii that like P. elegans tolerate a wide range of salinities (from 4 to $42 \mathrm{psu}$ ) and temperatures (from $0^{\circ} \mathrm{C}$ to $30^{\circ} \mathrm{C}$ ); adults of C. pagurus and H. americanus are stenohaline that can tolerate a range of salinity variable from 20 to $40 \mathrm{psu}$ and of temperature from 8 to $20^{\circ} \mathrm{C}$. The lowest protein concentration was found in the most primitive subclass Hoplocarida of the tested crustaceans, all the rest belonging to Eumalacostraca. The lowest density was confirmed in the freshwater crayfish A. leptodactylus, whose hemolymph has an inorganic ion concentration about one-third of the marine species from the same infraorder Astacidea.

Several studies showed that the protein scale on a clinical serum refractometer, while correlated to protein concentration, sometimes overestimates the values returned by colorimetric assays of protein in fish serum [26, 30-32]. In Crustacea, our work confirms the data previously obtained from other authors suggesting the use of refractometry in order to measure total protein because of the ease, rapid mode of operation, and feasiblity in the field and laboratory $[22,23,25]$. As whole blood and plasma have not significantly different readings, refractometry can be also used in the field immediately after bleeding without centrifugation and anticoagulants.

The different level of correlation obtained in the different species is probably related to a difference in the contribution to hemolymph density of solutes other than protein. In fact, the colorimetric reagent reacts with peptide bonds to form a coloured complex, absorbance of which can be measured at $546 \mathrm{~nm}$. The intensity of colour is proportional to the number of peptide bonds and hence the protein concentration, while the refractometry measure is affected by all solutes in the sample. But the comparison of total protein values obtained with both methods and compared in a two-tailed paired $t$-test showed no significant difference, thus confirming the validity of the method.

Therefore, it is probably safe to assume that the equations reported here, at least for some purposes, may be a satisfactory estimation of blood protein concentration in other large marine crustaceans, especially if just knowing the relative change is sufficient.

The use of a refractometer to determine serum or blood protein concentration has a number of benefits over more complex methods. (1) The optical density refractometers themselves are relatively cheap and common in aquaculture plants for salinity checks. (2) The method provides immediate results and (3) the data are at least as reliable as those of commonly employed colorimetric methods that require samples to be centrifuged, stored, and analysed later. (4) Clotting of blood is not an issue as protein determinations through density can be performed rapidly using whole blood within the time it takes for the whole blood to start clotting.

\section{Acknowledgments}

This research was supported by Grant no. 6D4 from the Italian MiPAF to E. A. Ferrero and by INTERREG IIIA Transfrontaliero Adriatico "ANSERE." Collaboration by Fiorital spa with T. Scovacricchi and D. Mazzoni, and P. G. Giulianini is gratefully acknowledeged.

\section{References}

[1] L. E. Moore, D. M. Smith, and N. R. Loneragan, "Blood refractive index and whole-body lipid content as indicators of nutritional condition for penaeid prawns (Decapoda: Penaeidae)," Journal of Experimental Marine Biology and Ecology, vol. 244, no. 1, pp. 131-143, 2000.

[2] C. Rosas, E. L. Cooper, C. Pascual et al., "Indicators of physiological and immunological status of Litopenaeus setiferus wild populations (Crustacea, Penaeidae)," Marine Biology, vol. 145, no. 2, pp. 401-413, 2004.

[3] S. Lorenzon, P. G. Giulianini, M. Martinis, and E. A. Ferrero, "Stress effect of different temperatures and air exposure during transport on physiological profiles in the American lobster Homarus americanus," Comparative Biochemistry and Physiology A, vol. 147, no. 1, pp. 94-102, 2007.

[4] L. Hagerman, "Haemocyanin concentration of juvenile lobsters (Homarus gammarus) in relation to moulting cycle and feeding conditions," Marine Biology, vol. 77, no. 1, pp. 11-17, 1983.

[5] J.-C. Chen and P.-G. Chia, "Oxyhemocyanin, protein, osmolality and electrolyte levels in the hemolymph of Scylla serrata in relation to size and molt cycle," Journal of Experimental Marine Biology and Ecology, vol. 217, no. 1, pp. 93-105, 1997.

[6] S. Shafir, M. Tom, M. Ovadia, and E. Lubzens, "Protein, vitellogenin and vitellin levels in the hemolymph and ovaries during ovarian development in Penaeus semisulcatus (de Haan)," Biological Bulletin, vol. 183, pp. 394-400, 1992.

[7] E. Palacios, A. M. Ibarra, and I. S. Racotta, "Tissue biochemical composition in relation to multiple spawning in wild and pond-reared Penaeus vannamei broodstock," Aquaculture, vol. 185, no. 3-4, pp. 353-371, 2000.

[8] C. H. Lin and J. C. Chen, "Hemolymph oxyhemocyanin and protein levels and acid-base balance in the tiger shrimp Penaeus monodon exposed to copper sulfate," Journal of the World Aquaculture Society, vol. 32, no. 3, pp. 335-341, 2001.

[9] S. Lorenzon, P. G. Giulianini, S. Libralato, M. Martinis, and E. A. Ferrero, "Stress effect of two different transport systems on the physiological profiles of the crab Cancer pagurus," Aquaculture, vol. 278, no. 1-4, pp. 156-163, 2008.

[10] M. H. Depledge and P. Bjerregaard, "Haemolymph protein composition and copper levels in decapod crustaceans," Helgoland Marine Research, vol. 43, no. 2, pp. 207-223, 1989.

[11] L. M. Perazzolo, R. Gargioni, P. Ogliari, and M. A. A. Barracco, "Evaluation of some hemato-immunological parameters in 
the shrimp Farfantepenaeus paulensis submitted to environmental and physiological stress," Aquaculture, vol. 214, no. 14, pp. 19-33, 2002.

[12] G. F. Arcos, A. M. Ibarra, C. Vazquez-Boucard, E. Palacios, and I. S. Racotta, "Haemolymph metabolic variables in relation to eyestalk ablation and gonad development of Pacific white shrimp Litopenaeus vannamei Boone," Aquaculture Research, vol. 34, no. 9, pp. 749-755, 2003.

[13] F. Vargas-Albores and G. Yepiz-Plascencia, "Beta glucan binding protein and its role in shrimp immune response," Aquaculture, vol. 191, no. 1-3, pp. 13-21, 2000.

[14] M. Hall, R. Wang, R. van Antwerpen, L. Sottrup-Jensen, and K. Söderhäll, "The crayfish plasma clotting protein: a vitellogenin-related protein responsible for clot formation in crustacean blood," Proceedings of the National Academy of Sciences of the United States of America, vol. 96, no. 5, pp. 19651970, 1999.

[15] K. Montaño-Pérez, G. Yepiz-Plascencia, I. Higuera-Ciapara, and F. Vargas-Albores, "Purification and characterization of the clotting protein from the white shrimp Penaeus vannamei," Comparative Biochemistry and Physiology B, vol. 122, no. 4, pp. 381-387, 1999.

[16] J. E. Stewart, J. W. Cornick, and J. R. Dingle, "An electronic method for counting lobster (Homarus americanus Milene Edwards) hemocytes and the influence of diet on hemocyte numbers and hemolymph proteins," Canadian Journal of Zoology, vol. 45, pp. 1-12, 1967.

[17] D. M. Smith and W. Dall, "Blood protein, blood volume and extracellular space relationships in two Penaeus spp. (Decapoda: Crustacea)," Journal of Experimental Marine Biology and Ecology, vol. 63, no. 1, pp. 1-15, 1982.

[18] C. Pascual, A. Sánchez, E. Zenteno et al., "Biochemical, physiological, and immunological changes during starvation in juveniles of Litopenaeus vannamei," Aquaculture, vol. 251, no. 2-4, pp. 416-429, 2006.

[19] A. Sánchez-Paz, F. García-Carreño, J. Hernández-López, A. Muhlia-Almazán, and G. Yepiz-Plascencia, "Effect of shortterm starvation on hepatopancreas and plasma energy reserves of the Pacific white shrimp (Litopenaeus vannamei)," Journal of Experimental Marine Biology and Ecology, vol. 340, no. 2, pp. 184-193, 2007.

[20] N. B. Terwilliger, "Hemolymph proteins and molting in crustaceans and insects," American Zoologist, vol. 39, no. 3, pp. 589-599, 1999.

[21] S. M. Chan, S. M. Ratkin, and L. L. Keeley, "Characterization of the molt stages in Penaeus vannamei: setogenesis and hemolymph levels of total protein, ecdysteroids and glucose," Biological Bulletin, vol. 175, pp. 185-192, 1988.

[22] M. D. Oliver and A. B. MacDiarmid, "Blood refractive index and ratio of weight to carapace length as indices of nutritional condition in juvenile rock lobsters (Jasus edwardsii)," Marine and Freshwater Research, vol. 52, no. 8, pp. 1395-1400, 2001.

[23] G. Ozbay and J. G. Riley, "An analysis of refractometry as a method of determining blood total protein concentration in the American lobster Homarus americanus (Milne Edwards)," Aquaculture Research, vol. 33, no. 8, pp. 557-562, 2002.

[24] D. F. Leavitt and R. C. Bayer, "A refractometric method of determining serum protein concentration in the American lobster," Aquaculture, vol. 12, no. 2, pp. 169-171, 1977.

[25] B. D. Paterson, G. W. Davidson, and P. T. Spanoghe, "Measuring total protein concentration in blood of the western rock lobster (Panulirus cygnus George) by refractometry," in Proceedings of International Symposium on Lobster Health Management, pp. 110-115, Adelaide, Australia, September 1999.

[26] J. B. Alexander and G. A. Ingram, "A comparison of five of the methods commonly used to measure protein concentrations in fish sera," Journal of Fish Biology, vol. 16, no. 2, pp. 115-122, 1980.

[27] L. Ocampo, D. Patiño, and C. Ramírez, "Effect of temperature on hemolymph lactate and glucose concentrations in spiny lobster Panulirus interruptus during progressive hypoxia," Journal of Experimental Marine Biology and Ecology, vol. 296, no. 1, pp. 71-77, 2003.

[28] D. Da Silva-Castiglioni, B. K. Dutra, G. T. Oliveira, and G. B. Buckup, "Seasonal variations in the intermediate metabolism of Parastacus varicosus (Crustacea, Decapoda, Parastacidae)," Comparative Biochemistry and Physiology A, vol. 148, no. 1, pp. 204-213, 2007.

[29] L. Buckup, B. K. Dutra, F. P. Ribarcki et al., "Seasonal variations in the biochemical composition of the crayfish Parastacus defossus (Crustacea, Decapoda) in its natural environment," Comparative Biochemistry and Physiology A, vol. 149, no. 1, pp. 59-67, 2008.

[30] J. B. Hunn and I. E. Greer, "Colorimetric and refractometer estimates of total plasma protein in striped bass, Morone saxatilis (Walbaum)," Journal of Fish Biology, vol. 36, pp. 617618, 1990.

[31] R. M. G. Wells and N. W. Pankhurst, "Evaluation of simple instruments for the measurement of blood glucose and lactate, and plasma protein as stress indicators in fish," Journal of the World Aquaculture Society, vol. 30, no. 2, pp. 276-284, 1999.

[32] M. Riche, "Analysis of refractometry for determining total plasma protein in hybrid striped bass (Morone chrysops $\times M$. saxatilis) at various salinities," Aquaculture, vol. 264, no. 1-4, pp. 279-284, 2007. 

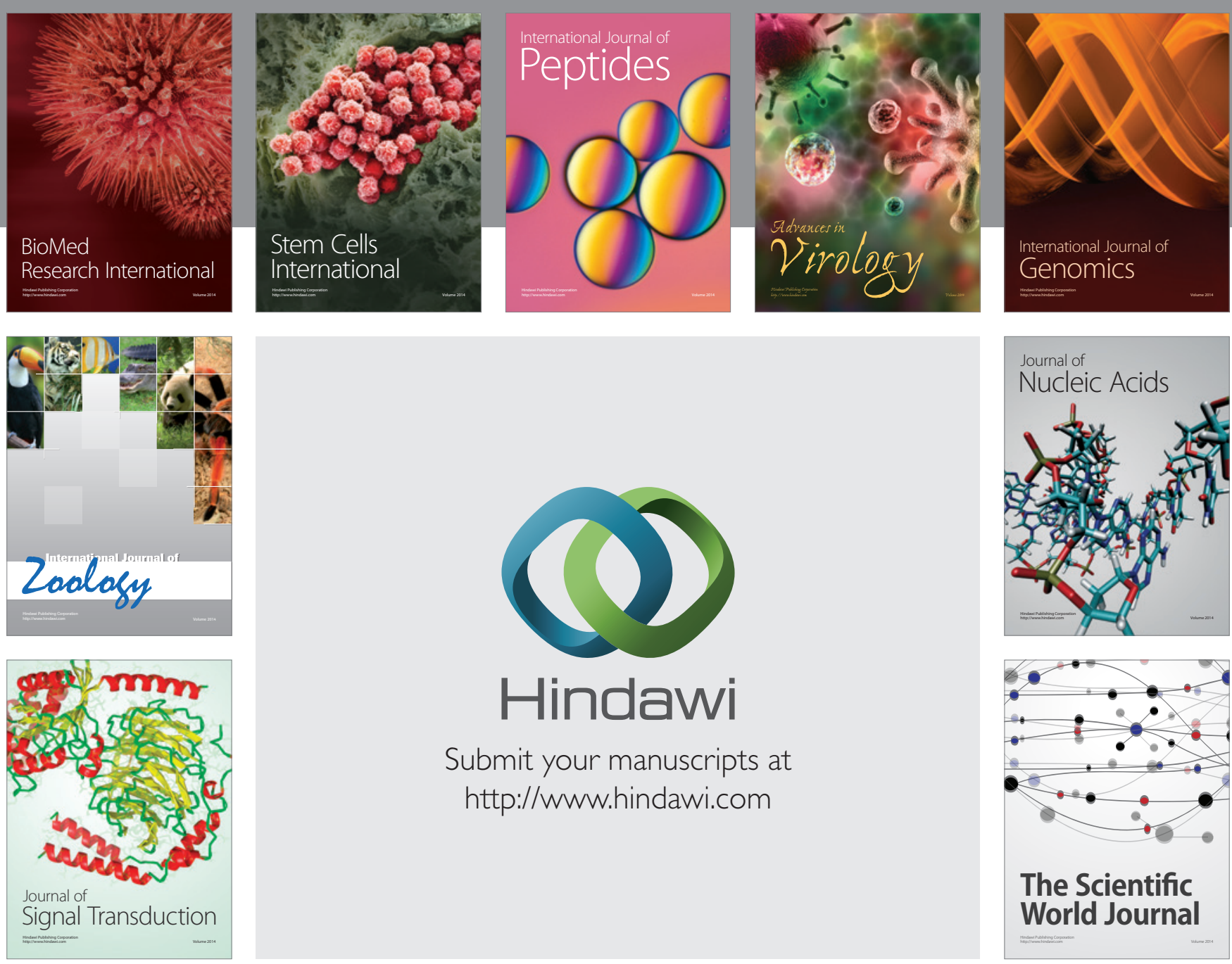

Submit your manuscripts at

http://www.hindawi.com
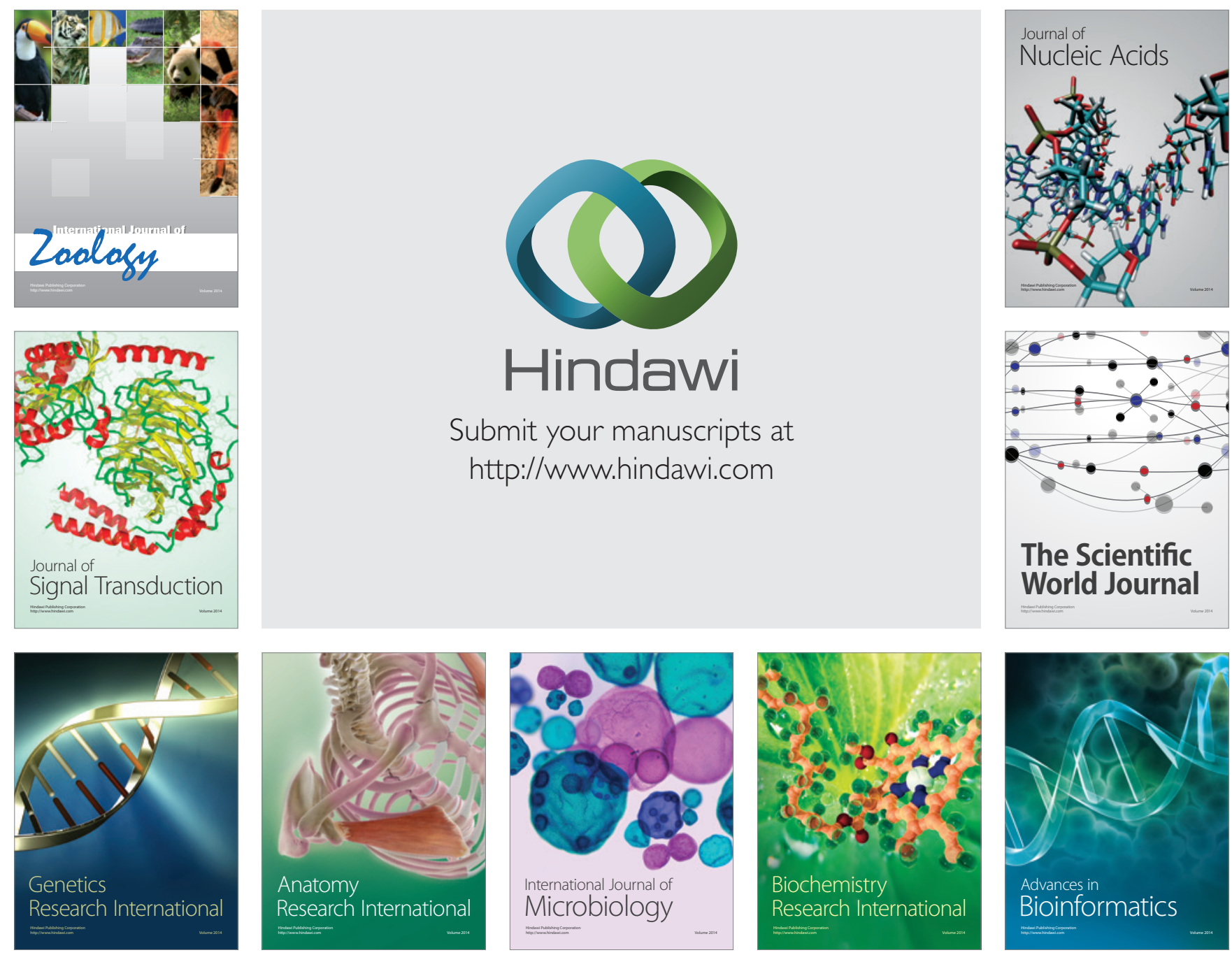

The Scientific World Journal
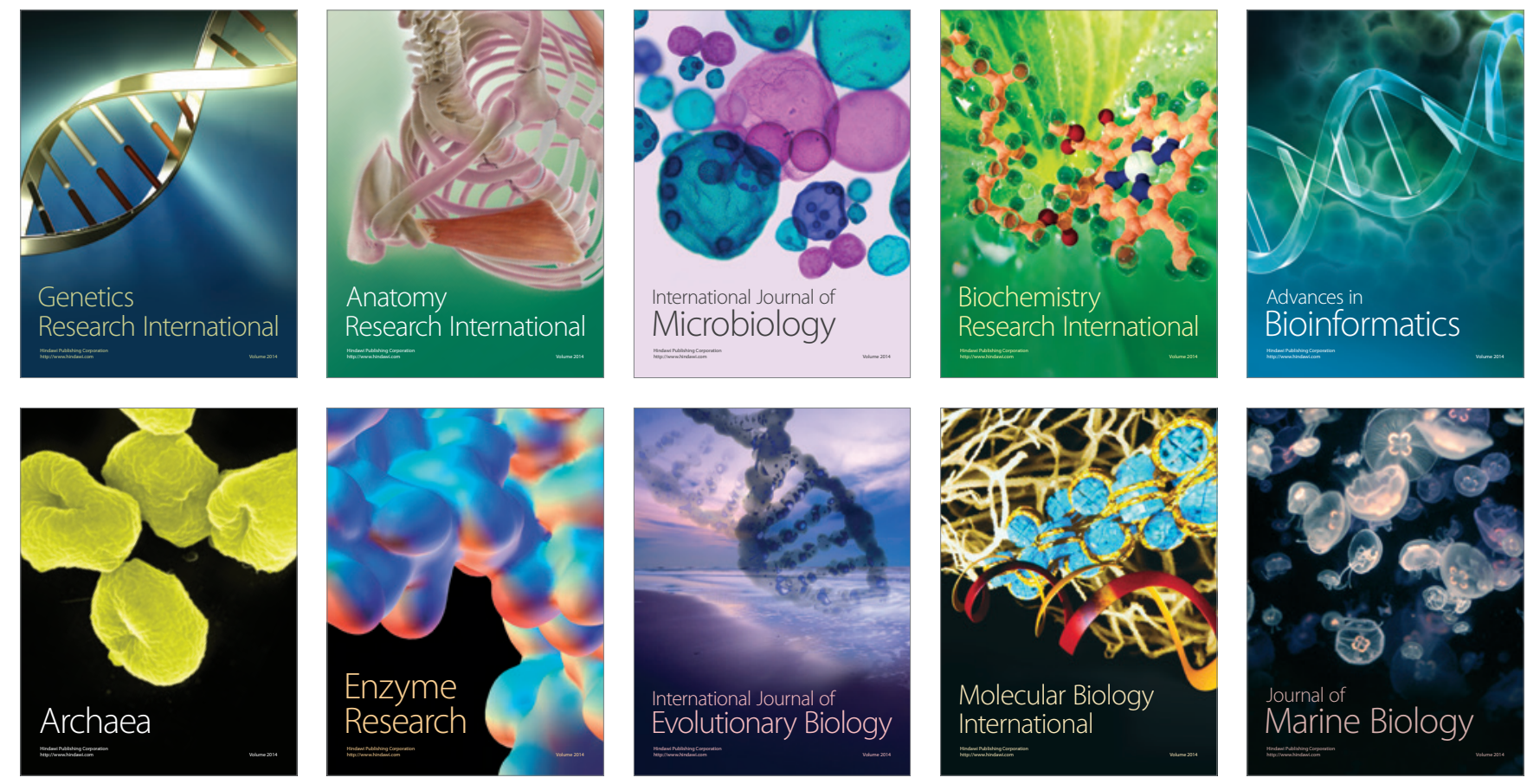